\title{
APLIKASI PENCATATAN ADMINISTRASI DAN ANALISIS KEUANGAN BAGI PELAKU USAHA DI BIDANG PERTANIAN
}

\author{
Eliana Wulandari dan Yosini Deliana \\ Fakultas Pertanian, Universitas Padjadjaran \\ E-mail: eliana.wulandari@unpad.ac.id
}

\begin{abstract}
ABSTRAK. Masyarakat pelaku usaha khususnya yang bergerak pada bidang pertanian masih banyak yang masih mengalami kesulitan dalam melakukan pencatatan maupun analisis keuangan usaha. Kegiatan pengabdian pada masyarakat ini dilakukan dengan menjalin kerjasama dengan mitra selaku pelaku usaha yang terkait dengan bidang pertanian, menggali permasalahan mitra dalam bidang pencatatan juga analisis keuangan, serta memberikan pelatihan terkait aplikasi pembukuan yang harapannya menjadi jawaban atas permasalahan pelaku usaha untuk kelancaran usahanya. Kegiatan pengabdian pada masyarakat ini dilaksanakan secara daring (metode virtual) dengan menggunakan platform meeting online dikarenakan sedang berlangsungnya wabah pandemi Covid-19 dengan tujuan untuk meningkatkan kesadaran pelaku usaha akan pentingnya administrasi pencatatan keuangan dan analisis keuangan, dan meningkatkan pengetahuan dan keterampilan pelaku usaha dalam penyusunan administrasi dan analisis keuangan. Materi yang diberikan pada kegiatan pelatihan ini yaitu mengenai jenis-jenis aplikasi pembukuan atau pencatatan dan analisis keuangan usaha dan bagaimana menggunakan aplikasi pencatatan tersebut.
\end{abstract}

Kata kunci: Pengabdian kepada masyarakat; Pencatatan dan analisis keuangan; Pelaku usaha pertanian

ABSTRACT. Many business people, especially those engaged in agriculture, still experience difficulties in recording and analyzing business finances. This community service activity was carried out by collaborating with partners as business actors related to the agricultural sector, exploring partners' problems in the field of financial recording and analysis, and delivering training related to book keeping applications which can be solved the problems of business actors for their business. This community service activity was conducted online (virtual method) using an online meeting platform due to the Covid-19 pandemic with the aim of increasing partners' awareness of the importance of financial recording and analysis, and increasing their knowledge and skills in administrative preparation and financial analysis. The material provided in this training activity is about the application types of accounting recording and business financial analysis, and how to use these recording applications.

\section{Keywords: Community service; Financial recording and analysis; Agricultural business actors}

\section{PENDAHULUAN}

Perkembangan usaha baik usaha kecil dan menengah cukup berkembang pesat. Usaha mikro kecil dan menengah berperan nyata dalam memberikan kontribusi pada sektor perekonomian (Sulistyowati, 2017). Usaha mikro kecil dan menengah bergerak pada banyak sektor ekonomi termasuk pertanian. Cakupan usaha mikro kecil dan menengah pada sektor pertanian dapat berupa usaha pemanfaatan barang-barang biologis (hidup). Barang-barang tersebut bersumber dari alam dan bertujuan untuk memenuhi kebutuhan atau usaha lainnya (Darwanto et al., 2018).

Perhatian terhadap sektor pertanian, peternakan, perikanan dan lainnya mulai banyak tertuju seiring dengan banyaknya industri dan usaha pertanian yang bermunculan seperti cafe, coffee shop, dan usaha rumahan yang menggunakan bahan baku hasil pertanian, peternakan, perikanan dan lainnya seperti pembuat kue, olahan ayam, olahan ikan (Rahmawati \& Rusli, 2017). Pada tahun 2015, jumlah usaha mikro kecil dan menengah mencapai 60,7 juta unit dimana mayoritas merupakan usaha dengan skala mikro (Rumbianingrum \& Wijayanangka, 2018). Usaha mikro, kecil dan menengah di Indonesia berkontribusi pada pembangunan ekonomi nasional yang dapat menggerakkan sektor riil, karena usaha mikro kecil dan menengah mempunyai fokus untuk mengembangkan industri rumah tangga, serta mendorong faktor produksi dan konsumsi. Sektor riil berkontribusi dalam menghasilkan barang dan jasa yang dapat dinikmati langsung ataupun tidak langsung (Rais, 2019).

Permasalahan yang seringkali terjadi pada usaha mikro kecil dan menengah yaitu dalam hal pengelolaan dana serta melakukan pencatatan akuntansi sehingga kesulitan dalam melakukan pinjaman ke bank, juga keuangan perusahaan bercampur dengan keuangan keluarga (Rais, 2019). Selain itu permasalahan juga terjadi pada usaha mikro kecil dan menengah diantaranya tidak akuratnya laporan keuangan yang mengakibatkan kesulitan dalam mengetahui laporan keuangan yang baik dan benar (Ria, 2018).

Laporan keuangan usaha mikro kecil menengah masih dicatat secara manual yaitu dengan cara mencatat dan menghitung transaksi ke buku catatan. Hal ini mengakibatkan ketidakefisienan. Transaksi yang setiap hari perlu dicatat dan dihitung serta dibuat laporannya menggunakan waktu yang tidak sedikit (Juhardi \& Khairullah, 2019). 
Kegiatan pengabdian pada masyarakat ini dilakukan dengan cara memberikan sosialisasi dan meningkatkan pengetahuan serta wawasan kepada para pelaku usaha mengenai apa saja aplikasi pencatatan administrasi keuangan dan analisis usaha sehingga kegiatan ini juga diharapkan mampu memudahkan para pelaku usaha dalam mengelola keuangannya. Selain itu diharapkan juga para pelaku usaha dapat memahami serta dapat mengoperasikan aplikasi untuk pencatatan administrasi dan analisis keuangan usaha yang dijalani.

Berdasarkan permasalahan pengelolaan keuangan dari para pelaku usaha, aplikasi pengelolaan keuangan dibutuhkan untuk membantu mencatat dan menghitung keluar masuknya keuangan dengan jelas agar laporan keuangan bisa dijadikan sebagai bahan evaluasi pada masa mendatang. Banyak aplikasi pencatatan keuangan yang dapat diinstal pada android, IOS, Mac dan juga Windows sehingga mudah untuk dibawa ke semua tempat dan relatif tidak terlalu sulit dalam penggunaannya.

\section{METODE}

Kegiatan pengabdian pada masyarakat ini dilaksanakan secara integratif dengan kegiatan kuliah kerja nyata mahasiswa (KKNM) secara virtual dengan sasaran kegiatan pengabdian kepada masyarakat ini adalah para pelaku usaha di bidang pertanian. Sehubungan dengan adanya pandemi Covid-19, maka calon peserta pelatihan diperoleh dari pencarian pelaku usaha di bidang pertanian pada daerah masing-masing tempat tinggal mahasiswa KKNM yaitu di Sumatera Barat, Jambi dan Jawa Barat. Terdapat sebanyak 38 orang pelaku usaha yang mengikuti kegiatan ini, dimana usaha yang digeluti para peserta pelatihan meliputi usaha yang bergerak dalam bidang agroindustri (pengolahan produkproduk pertanian) dan usaha penjualan produkproduk pertanian beserta hasil pengolahannya.

Waktu pelaksanaan kegiatan ini pada bulan Januari - Februari 2021. Tahapan pelaksanaan pelatihan meliputi identifikasi calon peserta pelatihan, persiapan, dan pelaksanaan pelatihan.

1. Identifikasi dan pendataan para pelaku usaha di bidang pertanian sebagai calon peserta pelatihan melalui wawancara mengenai:

a. Profil usaha

b. Kondisi dan permasalahan dalam melakukan pencatatan administrasi keuangan usaha

c. Analisa keuangan usaha

d. Kemampuan pemilik usaha dalam memaksimalkan fungsi aplikasi pencatatan dan analisa keuangan

2. Persiapan pelatihan:

a. Pembuatan video pelatihan b. Melakukan uji coba pemutaran video sesuai dengan petunjuk teknis dan memberikan feedback mengenai video yang ditampilkan

c. Melakukan revisi/edit video pelatihan sesuai dengan berbagai masukan

3. Pelaksanaan pelatihan:

a. Pemberian pemahaman terkait pentingnya pencatatan administrasi dan analisis keuangan yang baik

b. Penjelasan format pencatatan keuangan berbasis Android dan Windows

c. Penjelasan penggunaan beberapa aplikasi pencatatan keuangan berbasis Android dan Windows

\section{HASIL DAN PEMBAHASAN}

Para pelaku usaha masih banyak yang kurang memperhatikan pengelolaan keuangan dengan baik sehingga masih ada beberapa komponen biaya yang masih belum dimasukkan dalam perhitungan usaha dan tidak mengetahui berapa besar keuntungan atau kerugian yang diperoleh. Pelaku usaha khususnya di bidang pertanian masih banyak yang belum melakukan pencatatan usaha padahal pencatatan usaha dapat berperan penting dalam memperoleh akses pembiayaan usaha (Wulandari et al., 2017).

Berdasarkan hasil wawancara penggalian informasi kepada peserta pelatihan, diperoleh informasi bahwa peserta pelatihan sudah melakukan pencatatan usaha, tetapi tidak rutin atau belum digunakan sebagai pencatatan secara berkala ataupun pengarsipan. Secaraumum, pesertapelatihanbiasanya melakukan pencatatan usaha secara manual di buku. Pelaku usaha melakukan pencatatan keuangan secara manual dan sederhana dengan menggunakan buku (Jayanti \& Sastrawangsa, 2019; Suprapto et al., 2020) sehingga waktu yang dibutuhkan untuk membuat laporan keuangan pun menjadi lama (Suprapto et al., 2020). Terdapat peserta pelatihan yang melakukan analisis usaha secara verbal (tidak tertulis) hanya melalui diskusi keluarga. Pencatatan keuangan yang dilakukan oleh mitra belum rutin, sehingga analisisnya pun tidak dilakukan secara tertulis. Mitra berpendapat bahwa indikator keberhasilan dari usaha mitra yaitu besarnya pendapatan dari usaha mitra, sehingga kebutuhan ekonomi mitra sudah terpenuhi. Pada masa pandemi Covid-19 ini, pemasukan utama di keluarga mitra berasal dari usaha yang dijalani oleh mitra. Analisis pembiayaan atau keuangan yang dilakukan peserta pelatihan biasanya melalui diskusi yang membahas untung atau rugi usahanya tersebut secara tidak tertulis. Ada juga yang sudah melakukan pencatatan keuangannya di komputer menggunakan Ms.Word atau Excel, namun belum secara rutin. 


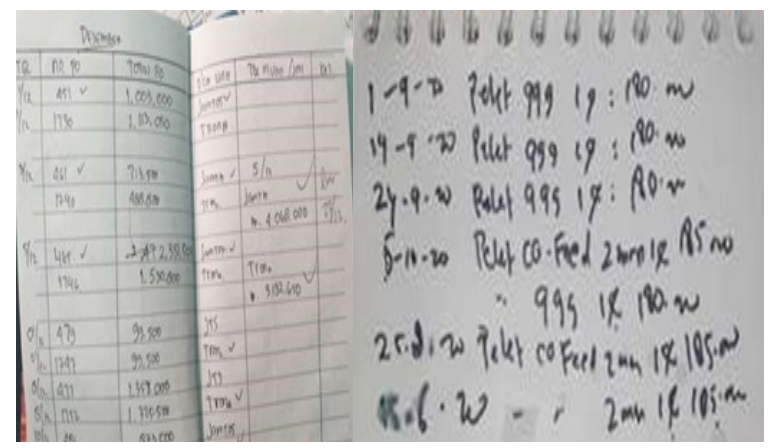

Gambar 1. Pencatatan penjualan peserta pelatihan secara manual di buku atau notes

Peserta pelatihan belum pernah mendapatkan informasi mengenai penggunaan aplikasi berbasis Android atau bahkan mengikuti pelatihan pencatatan administrasi keuangan. Peserta pelatihan tertarik untuk mengikuti pelatihan mengenai pencatatan administrasi keuangan karena harapannya mitra bisa lebih rajin lagi untuk mencatat dan lebih detail lagi pencatatannya. Peserta pelatihan mengharapkan dengan mengikuti pelatihan pencatatan keuangan dapat termotivasi agar pencatatan usahanya lebih konsisten. Selain itu, peserta pelatihan juga menuturkan ketertarikan pelatihan pada aplikasi berbasis Android sehingga pencatatan usaha bisa dilakukan secara lebih mudah dan lebih tertib secara administrasi. Kegiatan pelatihan pengelolaan keuangan dapat membantu peserta pelatihan mudah dalam mengetahui berapa besarnya pengeluaran dan penghasilan pada setiap bulan (Jayanti \& Sastrawangsa, 2019).

Kegiatan ini berhasil dilakukan dengan baik yang diindikasikan dengan respons yang positif dari para peserta yang hadir dan keaktifan para peserta dalam bertanya serta berdiskusi untuk mendapatkan informasi yang lebih jelas mengenai materi dan aplikasi yang diinformasikan. Peserta pelatihan menganggap pencatatan dan analisis keuangan penting dilakukan sehingga ketika kegiatan pelatihan berlangsung banyak peserta pelatihan yang aktif berdiskusi dan bertanya mengenai aplikasi-aplikasi pencatatan dan analisis keuangan. Selain itu, para peserta menjawab dengan antusias dan bersikap optimis mengenai kegiatan ini dan tertarik untuk mengetahui cara penggunaan aplikasi lebih lanjut. Kegiatan pengabdian pada masyarakat ini juga menjelaskan dan menyajikan beberapa aplikasi pencatatan dan analisis keuangan seperti Si Apik, Catatan Keuangan, Buku Kas, serta Ms. Excel dengan cara penggunaannya.

Secara garis besar pencatatan melalui digital menggunakan aplikasi Android ataupun menggunakan Windows terdiri dari penjualan, laporan laba rugi, laporan perubahan modal, harga pokok penjualan, dan laporan arus kas. Jenis pencatatan ini ditetapkan berdasarkan kebutuhan dan kondisi dari usaha. Pencatatan penjualan terbagi menjadi pencatatan per pelanggan dan rekapan penjualan per bulan. Pencatatan per pelanggan digunakan karena pesanan setiap pelanggan dengan banyak item dan untuk memudahkan melihat detail pesanan. Rekapan penjualan per bulan dicatat per pelanggan untuk mengetahui alur piutang dan pelunasannya.

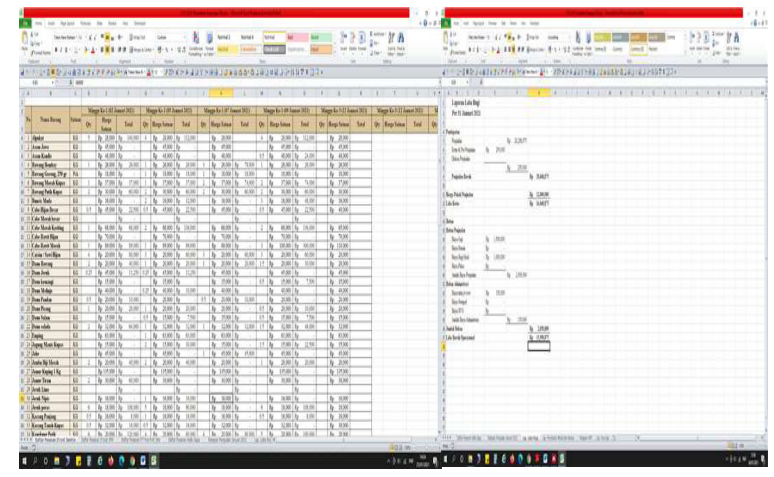

Gambar 2. Pencatatan usaha meggunakan Windows (Ms. Excel)

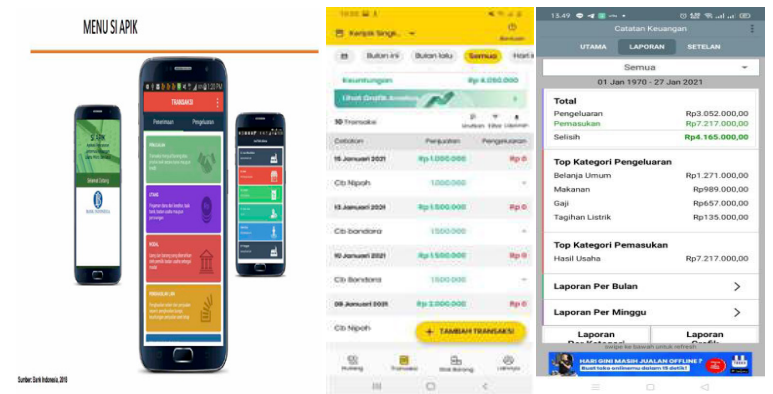

Gambar 3. Aplikasi-aplikasi Pencatatan dan Analisis Keuangan berbasis Android

Saat pemaparan aplikasi pencatatan dan analisis keuangan, peserta pelatihan memberikan pertanyaan tentang berbagai hal yang terkait dengan pencatatan. Ini membuktikan bahwa adanya ketertarikan mitra dengan kegiatan yang sedang berlangsung. Peserta juga menanyakan mengenai pengaksesan aplikasi pada laptop atau komputer. Pada dasarnya aplikasiaplikasi pencatatan keuangan pada Android, Iphone dan website sama saja. Pertanyaan lainnya yaitu mengenai keefektifan penggunaan aplikasi-aplikasi pencatatan keuangan dan pertanyaan mengenai bagaimana cara mendisiplinkan diri menggunakan aplikasi-aplikasi pencatatan keuangan tersebut.

Peserta pelatihan mengatakan bahwa menjadi lebih tahu aplikasi-aplikasi yang dapat digunakan untuk melakukan pencatatan dan analisis keuangan karena dijelaskan secara detail sehingga peserta pelatihandapatmempertimbanganaplikasimanayang akan digunakan sesuai dengan kebutuhannya. Selain itu peserta pelatihan mengatakan bahwa akan mulai mendisiplinkan diri dalam melakukan pencatatan dan analisis keuangan untuk usahanya menggunakan aplikasi yang telah ditampilkan pada video pelatihan supaya usahanya semakin berkembang lagi. Peserta pelatihan juga mengungkapkan bahwa penggunaan 
Ms. Excel tidak sulit, karena ada formula, sehingga mudah untuk digunakan dan tidak perlu dihitung manual. Selain itu juga dengan menggunakan Ms. excel ini memudahkan pelaku usaha untuk melakukan analisis usahanya.

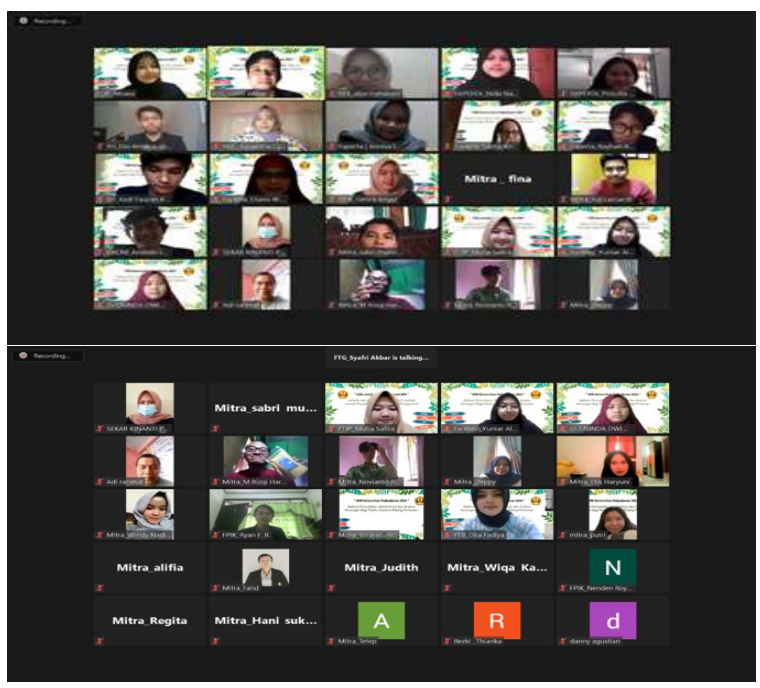

Gambar 4. Pelaksanaan Pelatihan Pencatatan dan Analisis Keuangan

\section{SIMPULAN}

Program pengabdian pada masyarakat ini bertujuan untuk membantu para pelaku usaha khususnya di bidang pertanian dengan cara pengenalan pencatatan keuangan menggunakan aplikasi sehingga keuangan dapat dipantau dengan baik dan mudah. Pada pelaksanaan pengabdian pada masyarakat ini juga menjelaskan dan menyajikan beberapa aplikasi seperti Si Apik, Catatan Keuangan, Buku Kas, serta Ms. Excel dan cara penggunaannya. Kegiatan ini berlangsung dengan baik dan berjalan dengan lancar. Metode pelaksanaan yang digunakan adalah penyuluhan dan pelatihan pencatatan usahatani secara online menggunakan platform online meeting. Partisipasi peserta pelatihan dalam pelaksanaan program ini dinilai sangat baik. Peserta pelatihan aktif melakukan interaksi dan diskusi dalam pelaksanaan program ini.

\section{UCAPAN TERIMAKASIH}

Kami menyampaikan terimakasih kepada para pelaku usaha di bidang pertanian yang telah bersedia menjadi peserta dalam kegiatan pengabdian pada masyarakat ini. Kami juga berterimakasih kepada Direktorat Riset dan Pengabdian pada Masyarakat Universitas Padjadjaran yang telah membantu dalam pendanaan kegiatan pengabdian pada masyarakat ini.

\section{DAFTAR PUSTAKA}

Darwanto, Raharjo, S. T., dan Setiawan, A. H. 2018. Pengembangan Produksi Usaha Mikro, Kecil dan Menengah (UMKM) Sektor Pertanian Berbasis Potensi Lokal. Jurnal Riset Ekonomi Manajemen (REKOMEN). 1 (2) 27-36.

Jayanti, N. K. D. A., dan Sastrawangsa, G. 2019. Pemanfaatan Teknologi Informasi bagi Industri Konfeksi di Kecamatan Gianyar. Dharmakarya. 8 (2) 115-118.

Juhardi, U., dan Khairullah. 2019. Sistem Pencatatan dan Pengolahan Keuangan pada Aplikasi Manajemen Keuangan E-Dompet Berbasis Android. Journal of Technopreneurship and Information System. 2 (1) 24-29.

Rahmawati, dan Rusli, A. 2017. Pelatihan dan Pembimbingan Pembuatan Sistem Laporan Keuangan Sederhana pada UKM di Kota Palopo. Jurnal Akuntansi. 3 (1), 35-38.

Rais, M. 2019. Analisis Sistem Pencatatan Akuntansi pada Usaha Mikro Kecil dan Menengah Kota Baubau. Jurnal Ilmiah Akuntansi Manajemen. 2 2598-0696.

Ria, A. 2018. Analisis Penerapan Aplikasi Keuangan Berbasis Android. Sosio E-Kons. 10 (3) $207-$ 219.

Rumbianingrum, W, dan Wijayanangka, C. 2018. Pengaruh Literasi Keuangan terhadap Pengelolaan Keuangan UMKM. Jurnal Manajemen dan Bisnis. 2 (3) 155-165.

Sulistyowati, Y. 2017. Pencatatan Pelaporan Keuangan UMKM (Study Kasus di Kota Malang). Referensi : Jurnal Ilmu Manajemen dan Akuntansi. 5 (2) 49.

Suprapto, P. A., Dewi, K. C., Pratiwi, N. M. W. D., dan Sarja, N. L. A. K. Y. 2020. Pemberdayaan Badan Usaha Milik Desa Panca Sari Amerta, Desa Singapadu Kaler. Dharmakarya. 9 (4) 211-215.

Wulandari, E., Ernah, dan Supyandi, D. 2017. Penguatan Kemampuan Manajerial Petani Melalui Pelatihan dan Pendampingan Pencatatan Finansial Usaha Tani di Kabupaten Cianjur. Dharmakarya. 6 (3) 189-192. 